\title{
ANALISIS PENGARUH BIAYA DISTRIBUSI, BIAYA PROMOSI DAN JUMLAH PEGAWAI PEMASARAN TERHADAP HASIL PENJUALAN
}

\author{
Nerys Lourensius L.T \\ STIE IEU Yogyakarta
}

\begin{abstract}
This study aims to determine: (1) significant relationship between the cost of distribution, promotion and marketing headcount simultaneously against the sale at PT. Prima Athatama Magelang. (2) significant relationship between the cost of distribution, promotion and marketing headcount simultaneously against the sale at PT. Prima Athatama Magelang. The research was conducted at PT. Prima Athatama Magelang. Data collection techniques used were interviews and observation techniques. The data obtained are qualitative and quantitative data. Peneitian objects are data on the number of distribution costs, promotional costs, the sheer number of employees of marketing and sales results have been achieved. In this study proposed two hypotheses: (1) Is there a significant relationship between the cost of distribution, promotion and marketing headcount partially against the sale at PT. Prima Athatama Magelang. (2) Is there a significant relationship between the cost of distribution, promotion and marketing headcount simultaneously against the sale at PT. Prima Athatama Magelang. Data analysis test of two hypotheses to be used multiple linear regression analysis with significance level of $5 \%$, then before the data in the analysis test is conducted prior $\mathrm{t}$ test, $\mathrm{F}$ test, test $\mathrm{R}$ (determination) and classical assumption.

The results showed that: (1) distribution costs, variable costs of promotion and marketing of variable number of employees partially have significant influence on sales results (Y) in PT. Prima Athatama Magelang evident because of the test results obtained by value $t$ count $t$ is greater than $t$ Tabel is 3,475>1,672. (2) distribution costs, variable costs of promotion and marketing of variable number of employees simultaneously have a significant impact on sales results (Y) in PT. Prima Athatama Magelang evident because of the test results obtained F count F count larger than F Tabel, namely 204, 811> 3,162. The results showed jointly have a significant impact on sales results (Y) in PT. Prima Athatama MagelangKata.
\end{abstract}

Keywords: distribution cost, promotion cost, marketing of variable number of employees and sales result 
PENDAHULUAN

Sesuai dengan prinsip ekonomi maka perusahaan dituntut untuk dapat mendayagunakan secara optimal segala sumber daya yang dimiliki. Tetapi tidak sedikit perusahaan yang sulit untuk memperbesar produksinya karena persaingan yang ketet. Oleh karena itu perusahaan harus selalu berusaha mengubah cara produksi yang tradisional dengan cara yang modernisasi yang selalu memacu produktifitas karyawan.

Suatu perusahaan memproduksi barang dengan kualitas yang baik, harga relative murah dibandingkan pesaing dan secara luas tersebar ke berbagai tempat tetapi apabila calon pembeli tidak diberi tahu adanya produk tersebut, diingatkan atau dibujuk untuk membelinya, konsumen akan bisa membayangkan bahwa produk tersebut tidak akan bisa laku dipasaran dan segala sesuatu yang telah dilakukan akan sia-sia. Perusahaan yang baru berdiri pun harus mempromosikan produknya untuk memberitahukan bahwa dipasar ada produk baru, tetapi juga

untuk produsen yang produknya mulai memasuki tahap pertumbuhan dalam siklus kehidupan produknya ini dapat menggunakan promosi yang sifatnya membujuk. Promosi yang sifatnya mengingatkan dilakukan terutama untuk mempertahankan merk dan image produk di hati konsumennya dan ini perlu dilakukan selama tahap kedewasaan di dalam siklus kehidupan barang atau jasa sebagai produksinya.

Semua perusahaan bertujuan agar produk yang dihasilkan dapat dikomsumsi secara luas oleh pasar sasaran. Oleh karena itu perusahaan berusaha mendapatkan perhatian serta ketertarikan khalayak ramai, perusahaan juga berupaya mempengaruhi serta membujuk calon konsumen agar mau mengkonsumsi produk yang dihasilkan perusahaan tersebut. Maka dari itu perusahaan dituntut dapat menciptakan kebijakan pemasaran yang tepat agar dapat mempengaruhi konsumen dalam pemilihan produk yang akan menciptakan permintaan bagi perusahaan, salah satu aspek yang cukup penting dalam manajemen pemasaran adalah saluran distribusi. Tujuan pemasaran secara langsung atau tidak langsung untuk memperlancar arus perpindahan barang dari produsen ke konsumen. Begitu juga dengan promosi dimana untuk memperkenalkan dan menarik konsumen terhadap produk yang dihasilkan. Untuk dapat mencapai tujuan perusahaan salah satu usaha yang dilakukan adalah dengan mengoptimalkan saluran distribusi dan promosi.

$$
\text { Pelaksanaan fungsi saluran }
$$
distribusi tersebut membutuhkan pengorbanan biaya dan penggunaan biaya dalam fungsi-fungsi distribusi tersebut 
diantaranya memperluas dan mengembangkan jaringan pemasaran yang berupa saluran distribusi. Melalui kegiatan promosi dan distribusi berusaha untuk meningkatkan hasil penjualan supaya perusahaan dapat meningkatkan dan memaksimalkan barang yang diproduksinya.

Pelaksanaan promosi dan distribusi yang direncanakan diarahkan dan dikendalikan dengan baik akan menyebabkan perusahaan dapat bertahan dalam persaingan yang ketat. Perusahaan harus dapat memilih sarana atau bentuk promosi yang tepat agar kegiatan promosi dapat berjalan secara efektif dari segi biaya yang dikeluarkan, waktu dan tenaga. Dengan adanya sarana pemasaran dan distribusi yang baik akan memadahi, diharapkan penyalur barang dari produsen ke konsumen berjalan dengan lancar sehingga hasil pemasaran produk dapat ditingkatkan dan dapat diketahui bahwa perusahaan bukan hanya sematamata untuk memproduksi saja akan tetapi juga mempertimbangkan penyalur hasil produksi ke pasar.

Disamping itu selain promosi dan distribusi perusahaan juga senantiasa menggunakan alat perusahaan seperti karyawan/tenaga kerja yang berkompeten dan menguasai apa yang perusahaan inginkan. Karyawan/tenaga kerja sangat penting untuk kelancaran perusahaan dalam meningkatkan hasil yang maksimal,
Oleh karena itu dalam pemilihan karyawan / tenaga kerja harus senantiasa mengutamakan kinerja dan kreatifitas dalam bekerja.

\section{LANDASAN TEORI}

\section{A. Definisi Pemasaran}

Pemasaran adalah "suatu proses sosial yang didalamnya individu dan kelompok mendapatkan apa yang mereka butuhkan dan inginkan dengan menciptakan, menawarkan, dan secara bebas mempertukarkan produk yang bernilai dengan pihak lain", (Kotler, 2002).

Pemasaran adalah "suatu sistem keseluruhan dari kegiatan-kegiatan usaha yang ditujukan untuk merencanakan, menentukan harga, mempromosikan, dan mendistribusikan barang dan jasa yang dapat memuaskan kebutuhan baik kepada pembeli yang ada maupun pembeli potensial" (Bashu Swastha, 2012).

Inti dari pemasaran adalah mengidentifikasi dan memenuhi kebutuhan manusia dan sosial. Konsep pemasaran adalah sebuah falsafah bisnis yang menyatakan bahwa pemuasan kebutuhan konsumen merupakan syarat ekonomi dan sosial bagi kelangsungan hidup perusahaan. Apabila orientasi dari konsep tersebut bertolak dari produk perusahaan, dan memandangsebagai tugas perusahaan adalah penjualan dan promosi untuk menstimulir volume penjualan yang menguntungkan, maka 
konsep pemasaran mengajarkan bahwa kegiatan pemasaran suatu perusahaanharus dimulai dengan usaha mengenal, merumuskan keinginan dan kebutuhan dari konsumennya.

\section{B. Konsep Pemasaran}

Pemasaran adalah suatu proses sosial dan manajerial dimana individu dan kelompok mendapatkan kebutuhan dan keinginan mereka dengan menciptakan, menawarkan dan bertukar sesuatu yang bernilai satu sama lain (Philip Kotler, 1995). Sedangkan menurut Wiliam J. Stanton (1978) pemasaran adalah suatu sistem keseluruhan dari kegiatan-kegiatan bisnis yang ditujukan untuk merencanakan, menentukan harga, mempromosikan dan mendistribusikan barang dan jasa yang memuaskan kebutuhan konsumen.

Dari pendapat di atas dapat disimpulkan bahwa pemasaran sebagai suatu system dari kegiatan-kegiatan yang saling berhubungan, sehingga konsumen mendapatkan kebutuhan dan keinginan sertakepuasan.

Dalam melakukan kegiatan-kegiatan pemasaran yang efisien, efektif dan bertanggung jawab serta dapat berpedoman pada salah satu filosofi pemasaran. Ada lima filosofi pemasaran yang mendasari cara organisasi melakukan kegiatan-kegiatan pemasarannya (Philip Kotler, 2000), yaitu:
1. Konsep Berwawasan Produksi. Konsep berwawasan produksi berpendapat bahwa konsumen akan memilih produk yang mudah didapat dan murah harganya.

2. Konsep Berwawasan Produk. Konsep berwawasan produk berpendapat bahwa konsumen akan memilihproduk yang menawarkan mutu, kinerja terbaik, atau hal-hal inovatif lainnya.

3. Konsep Berwawasan Menjual. Konsep berwawasan menjual berpendapat bahwa konsumen dibiarkan saja, konsumen tidak akan membeli produk organisasi dalam jumlah cukup, artinya konsumen enggan membeli dan harus didorong supaya membeli, serta perusahaan mempunyai banyak cara promosi dan penjualan yang efektif untuk merangsang pembeli.

4. Konsep Berwawasan Pemasaran. Konsep berwawasan pemasaran berpendapat bahwa kunci untuk mencapai tujuan organisasi terdiri dari penentuan kebutuhan dan keinginan pasar sasaran serta memberikan kepuasan yang diinginkan secara lebih efektif dan efisien dari pada saingannya.

William J. Stanton, menyatakan bahwa konsep pemasaran adalah sebuah falsafah bisnis yang menyatakan bahwa pemuasan kebutuhan konsumen merupakan syarat ekonomi dan sosial bagi kelangsungan hidup perusahaan. 
Penggunaan konsep pemasaran bagi sebuah perusahaan dapat menunjang berhasilnya bisnis yang dilakukan. Sebagai falsafah bisnis, konsep pemasaran tersebut disusun dengan memasukkan tiga elemen pokok, yaitu :

a. Orientasi konsumen/pasar/pembeli.

b. Volume penjualan yang menguntungkan.

c. Koordinasi dan integrasi seluruhan kegiatan pemasaran.

Philip Kotler (1995) mengemukakan konsep berwawasan pemasaran, berpendapat bahwa untuk mencapai tujuan organisasi terdiri dari penentu kebutuhan dan keinginan pasar sasaran serta memberikan kepuasan yang diinginkan secara lebih efektif dan efisien dari para saingannya. Konsep berwawasan pemasaran bersandar pada empat pilar utama, yaitu: pasar sasaran, kebutuhan pelanggan, pemasaran yang terkoordinir serta keuntungan.

Konsep berwawasan menjual memandang mulai dari dalam ke luar, mulai dengan pabrik, memutuskan perhatian pada produk yang ada dan membutuhkan penjualan serta promosi untuk menghasilkan penjualan yang menguntungkan.

\section{Memperhatikan definisi-definisi} tersebut diatas, dapat diketahui bahwa adanya kesepakatan oleh para ahli pemasaran yaitu : suatu kegiatan usaha yang diarahkan untuk memuaskan keinginan dan kebutuhan yang berupa barang ataupun jasa. Definisi pemasaran yang dianggap luas adalah: pemasaran yaitu suatu sistem keseluruhan dari kegiatan-kegiatan bisnis yang mempromosikan dan mendistribusikan barang dan jasa yang memuaskan kebutuhan baik kepada pembeli yang ada maupun pembeli potensial (Swasta, dan Irawan, 2002: 5).

Berdasarkan uraian pengertian pemasaran diatas maka terdapat unsurunsur penting dalam pemasaran, meliputi:

1. Kebutuhan dan keinginan konsumen

2. Adanya kebutuhan produk yang dianggap mampu memuaskan kebutuhan.

3. Proses pemasaran kebutuhan dan keinginan dilakukan dengan cara tertentu yaitu melalui cara pertukaran.

4. Adanya pertukaran akan membutuhkan tempat untuk pertukaran yaitu pasar.

Pemasaran mempunyai peran yang demikian penting dalam meningkatkan kegunaan barang yang semula di tempat lain pada waktu tertentu tidak berguna maka di suatu tempat sewaktu-waktu akan sangat ditujukan untuk merencanakan, menentukan harga, diperlukan dan diinginkan guna memenuhi kebutuhan untuk meningkatkan taraf hidup konsumen. Pemenuhan kebutuhan yang semakin meningkat mendorong perusahaan untuk mengadakan produksi 
yang besar-besaran yang didukung antara lain oleh promosi dan distribusi yang efektif.

Fungsi Pemasaran

Proses pemasaran perlu dilakukan oleh setiap perusahaan, karena dengan pemasaran kegunaan tempat, waktu dan pemikiran dan kegiatan pemasaran (Swastha dan Sukotjo, 2002: 196).Kegiatan pemasaran tersebut di dalamnya mempunyai fungsi pemasaran, yaitu :

1. Fungsi pertukaran. Fungsi pertukaran meliputi pembelian dan penjualan. Fungsi ini berkaitan dengan pertukaran barang dari penjual ke pembeli. Fungsi pembelian dilakukan oleh pembeli untuk memilih jenis barang yang akan dibeli, kualitas yang diinginkan, kualitas yang memadai dan penyediaan uang yang sesuai. Fungsi penjulan paling luas meliputi kegiatan untuk mencapai pasar dan mempengaruhi permintaan.

2. Fungsi penyedia fisik. Fungsi penyedia fisik meliputi pengangkutan dan penyimpanan. Fungsi pengangkutan dan penyimpanan berkaitan dengan pemindahan barang-barang dari tempat produksi ke konsumen. Selain itu fungsi tersebut berkaitan pula dengan penyimpanan barang-barang sampai barang tersebut diperlukan oleh konsumen. Fungsi pengangkutan dapat akan menambah kegunaan produk yang ada yaitu dilakukan dengan kereta api, truk, kapal laut, dan pesawat udara, sedangkan fungsi penyimpanan dapat dilakukan di bagian produksi itu sendiri sampai di gudang umum.

3. Fungsi Standarisasi. Fungsi strandarisasi barang-barang dan grading serta pengumpulan informasi pasar. Fungsi ini dapat membantu pelaksanaan dari fungsi-fungsi lainnya. Fungsi pembelian bertujuan untuk menyediakan dana, melayani penjualan kredit atau menanggung kerugian perusahaan, yang semuanya merupakan kegiatan yang selalu ada di dalam semua kegiatan bisnis. Standarisasi merupakan fungsi yang bertujuan menyederhanakan keperluan-keperluan pembeli dengan menciptakan golongan-golongan barng tertentu yang berdasarkan pada kriteria-kriteria mengidentifikasikan golongan barang tersebut ke dalam berbagai tingkat kualitas.

4. Fungsi penunjangFungsi penunjang yaitu pengumpulan informasi pasar, bertujuan mengumpulkan berbagai macam informasi yang dapat dipakai oleh manager pemasaran untuk mengambil keputusan.

\section{Pengertian Marketing Mix}

Marketing mix merupakan kombinasi empat besar pembentuk inti pemasaran sebuah perusahaan sesuai dengan definisi berikut ini "Marketing mix 
adalah kombinasi dari empat variabel atau kegiatan yang merupakan inti dari sistem pemasaran perusahaan, yakni : produk, struktur harga, kegiatan promosi, dan sistem distribusi (Lupiyoadi, 2001: 61). Pengertian tersebut dapat diketahui bahwa di dalam marketing mix terkandung empat variabel, yaitu : produk, harga, promosi, dan sistem distribusi dimana keempat variabel itu saling berhubungan.

1. Penggolongan barang menurut tingkat pemakaian dan kongkritnya barang (Swastha dan Sukotjo: 2002, 194) yaitu :

A. Barang tahan lama

Barang tahan lama adalah barang-barang yang secara normal dapat dipakai berulang kali, jadi dapat dipakai untuk jangka waktu yang relatif lama. Misalnnya: pakaian, almari, mesin tulis, kursi, dan sebagainya.

B. Barang tidak tahan lama

Barang tidak tahan lama adalah barang-barang yang secara normal hanya dapat dipakai satu kali atau bebrapa kali saja, artinya sekali barang itu dipakai akan habis, rusak, atau tidak dapat dipakai lagi. Misalnya : makanan, sabun, bahan baku, dan sebagainya.

C. Jasa
Jasa adalah kegiatan, manfaat, atau kepuasan yang ditawarkan untuk dijual. Misalnya : jasa reparasi, jasa potong rambut, jasa dokter dan sebagainya.

2. Penggolongan barang menurut tujuan pemakainnya oleh si pemakai, yaitu :

a. Barang konsumsi

Barang konsumsi adalah barang-barang yang dibeli untuk dikonsumsikan. Berdasarkan kebiasaan membeli dari konsumen, barang konsumsi dikelompokkan menjadi tiga golongan yaitu :

1) Barang konvenien yaitu barang yang mudah dipakai dan membelinya bisa disembarang tempat, misalnya rokok dan sabun

2) Barang shopping yaitu barang yang harus dibeli dengan mencari dahulu dan di dalam tekstil, perabot rumah tangga, dan sebagainya

3) Barang spesial yaitu barang yang mempunyai ciri khas dan hanya dapat dibeli di tempat tertentu saja, misalnya barang antik, perhiasan dan sebagainya. 
b. Barang industri

Barang industri adalah barang-barang yang dibeli untuk diproses lagi atau untuk kepentingan dalan industri, baik secara langsung maupun tidak langsung dipakai proses produksi. Dibedakan menjadi 3 : bahan baku, komponen dan barang setengah jadi, perlengkapan operasi, instalasi dan peralatan ekstra.

a. Saluran Distribusi

1. Pengertian Saluran Distribusi Sistem distribusi menurut C. Glenn Walters didefinisikan sebagai berikut, bahwa "sistem distribusi adalah sekelompok pedagang agen perusahaan yang mengkombinasikan antara pemindahan fisik dan nama dari suatu produk untuk menciptakan kegunaan bagi pasar terbuka (Swastha dan Irawan, 2002: 286)".

Lembaga-lembaga yang ikut bagian dalam penyaluran barang adalah :

a. Produsen

b. Perantara (pedagang dan agen)

c. Konsumen akhir atau pemakai industri

2. Penentuan Saluran Distribusi

Penentuan saluran distribusi harus mempertimbangkan distribusi yang sesuai dengan kebijakan perusahaan, untuk itu perusahaan harus melihat saluran yang sesuai dengan barang yang sedang dijual.

3. Fungsi saluran distribusi

Saluran distribusi untuk suatu barang adalah saluran yang digunakan oleh produsen untuk menyalurkan barang yang diproduksi kepada konsumen atau pemakai industri. Adapun lembaga-lembaga yang ikut mengambil bagian dalam penyaluran barang, yaitu: produsen, perantara dan konsumen akhir atau pemakai industri. Beberapa alternative saluran distribusi yang ada didasarkan pada jenis barang dan segmentasi pasarnya

b. Promosi

Usaha peningkatan penjualan perusahaan menjalankan berbagai upaya seperti memperbaiki dan memperluas penyaluran produknya serta meningkatkan pelayanan pada konsumen. Disamping itu perusahaan juga melakukan kegiatan promosi pemasaraan. Promosi dapat dikatakan sebagai komunikasi pemasaran adalah: "Kegiatan komunikasi yang dilakukan oleh pembeli dan penjual dan merupakan kegiatan yang membantu dalam pengambilan keputusan 
di bidang pemasaran serta mengarahkan pertukaran agar lebih memuaskan dengan cara menyadarkan semua pihak untuk berbuat lebih baik (Swastha dan Irawan, 2002: 345)". Pengertian promosi adalah :"suatu sistem keseluruhan dari kegiatankegiatan bisnis yang ditunjukkan untuk merencanakan, menentukan harga, mempromosikan dan mendistribusikan barang dan jasa untuk memuaskan kebutuhan baik kepada pembeli yang ada maupun pembeli yang potensial (Swastha dan Irawan, 2002 : 15)".

c. Pegawai/karyawan Pemasaran

$$
\text { Pegawai pemasaran adalah }
$$

Sumber daya manusia yang dimiliki oleh suatu suatu organisasi atau instansi yang sangat penting bagi peningkatan produktivitas atau kemajuan organisasi atau instansi dengan tujuan untuk mempercepat dan memperlancar arus kegiatan suatu organisasi atau instansi sehingga besar kecilnya jumlah sumber daya manusia yang dimiliki suatu organisasi atau instansi sangat berpengaruh terhadap target suatu organisasi atau instansi.

Tugas dan tanggung jawab pegawai pemasaran :

1. Berhubungan dengan hal yang menyangkut semua keperluan perusahaan

2. Membuat order dengan buyer
3. Menyerahkan order pada divisi order untuk memesan pada supplier atau supervisor untuk memenuhi order buyer

4. Membuat invoice order

5. Membuat packing list

6. Menentukan anggaran produksi

7. Membuat kebijaksanaan pemasaran produksi

8. Menentukan volume penjualan.

d. Penjualan

Menurut Basu Swastha DH (2004: 403) penjualan adalah interaksi antara individu saling bertemu muka yang ditujukan untuk menciptakan, memperbaiki, menguasai atau mempertahankan hubungan pertukaran sehingga menguntungkan bagi pihak lain. Penjualan diartikan juga sebagai usaha yang dilakukan manusia untuk menyampaikan barang bagi mereka yang memerlukan dengan imbalan uang menurut harga yang ditentukan atas persetujuan bersama.

\section{METODE PENELITIAN}

\section{A. Obyek Penelitian}

Penelitian ini dilakukan di PT Prima Athatama Jl. Perintis Kemerdekaan No. 21 Sanden Magelang Propinsi Jawa Tengah.

B. Waktu Penelitian 
Penelitian ini dilaksanakan pada bulan Maret sampai dengan bulan April 2013.

C. Definisi Operasional

Definisi operasional adalah suatu definisi diberikan oleh peneliti dan sekaligus memberikan penjelasan tentang cara mengukur masing-masing variabel penelitian. Misalnya dalam ukuran berat, ukuran waktu, ukuran kecepatan, ukuran unit, ukuran mata uang, ukuran persentase dan lain.

D. Metode Analisis Data

Analisis yang digunakan dalam penelitian ini adalah :

a. Analisis Kualitatif

Analisis kualitatif adalah suatu analisis dengan menggunakan teoriteori yang ada untuk menganalisis permasalahan yang ada dalam rangka menemukan bentuk pemecahan masalah tersebut. Dalam analisis kualitatif ini akan diuraikan mengenai penggunaan saluran distribusi, biaya promosi dan jumlah pegawai pemasaran terhadap hasil penjualan.

Di dalam analisis kualitatif ini distribusi, promosi dan pegawai pemasaran sangat berpengaruh besar terhadap hasil penjualan karena bila salah satu tidak dapat dilaksanakan otomatis perusahaan akan mengalami kerugian dan perusahaan tidak akan mendapatkan hasil penjualan yang maksimal.

b. Analisis Kuantitatif

Analisis kuantitatif adalah analisis yang digunakan berdasarkan angka-angka dan dapat diukur atau dihitung. Metode yang dipakai untuk mengetahui pengaruh biaya distribusi, promosi dan jumlah pegawai pemasaran terhadap hasil penjualan adalah analisis regresi linear sederhana atau regresi linear satu variable dan analisis regresi linear berganda atau regresi linear tiga variabel.

c.Uji Regresi

Uji regresi digunakan untuk menguji ada tidaknya pengaruh antara satu variabel dengan variabel lainnya. Variabel yang dipengaruhi disebut variabel terikat atau tidak bebas (dependent) dan variabel yang mempengaruhi disebut variabel bebas (independent). Disamping itu juga uji regresi dapat digunakan untuk tujuan peramalan atau prediksi dimana variabel yang diprediksikan merupakan variabel dependent

\section{HASIL DAN PEMBAHASAN}

A. Analisis Data Kuantitatif

Data Laporan Hasil Penjualan yang diperoleh adalah sebagai berikut :

Tabel 1.1 Laporan Hasil Penjualan 
Analis Pengaruh Biaya ... (Nerys Lourensius L.T)

\begin{tabular}{|c|c|c|c|c|c|}
\hline Bulan & 2008 & 2009 & 2010 & 2011 & 2012 \\
\hline Januari & 850 & 1150 & 1550 & 1760 & 1950 \\
\hline Februari & 820 & 1100 & 1590 & 1800 & 1870 \\
\hline Maret & 790 & 1300 & 1480 & 1680 & 2000 \\
\hline April & 880 & 1280 & 1560 & 1800 & 2110 \\
\hline Mei & 890 & 1175 & 1580 & 1830 & 2010 \\
\hline Juni & 950 & 1170 & 1610 & 1850 & 2050 \\
\hline Juli & 870 & 1007 & 1570 & 1760 & 2200 \\
\hline Agustus & 990 & 1120 & 1630 & 1880 & 2270 \\
\hline September & 1050 & 1095 & 1650 & 1910 & 2300 \\
\hline Oktober & 900 & 1001 & 1700 & 1890 & 2450 \\
\hline November & 1250 & 1150 & 1680 & 1950 & 2350 \\
\hline Desember & 1270 & 1200 & 1740 & 1970 & 2410 \\
\hline
\end{tabular}

Berdasarkan data diatas akan disajikan jumlah mean, modus, median, standar devisiasi dan rata-rata kenaikan dari tahun ke tahun hasil penjualan dari tahun 2008, 2009, 2010, 2011, 2012 sebagai berikut :

Tabel 1.2 Data Penjualan

\begin{tabular}{c|l|c|c|c|cc|} 
NO & KETERANGAN & 2008 & 2009 & 2010 & 2011 & 2012 \\
1 & Mean & 959.17 & 1145.67 & 1611.67 & 1840 & 2164.17 \\
\hline 2 & Median & 895 & 1150 & 1600 & 1840 & 2155 \\
3 & Modus & 790 & 1150 & 1480 & 1760 & 1870 \\
\hline 4 & Std Deviation & 157.507 & 91.341 & 72.467 & 85.174 & 192.281 \\
5 & Jumlah & 11510 & 13748 & 19340 & 22080 & 25970 \\
\hline & Rata-rata & & & &
\end{tabular}

Dari tabel data penjualan diatas menunjukkan hasil penjualan :

a) Tahun 2008 memiliki rata-rata hasil penjualan (mean) sebesar 959,17, median sebesar 895 , modus sebesar 790 dan standar devisiasi 157,507 dari hasil keseluruhan hasil penjualan dalam waktu satu tahun sebesar 11510.

b) Tahun 2009 memiliki rata-rata hasil penjualan (mean) sebesar 1145,67,

median sebesar 1150, modus 1150 dan standar devisiasi 91,341 dari hasil keseluruhan hasil penjualan dalam waktu satu tahun sebesar 13748 .

c) Tahun 2010 memiliki rata-rata hasil penjualan (mean) sebesar 1611,67, median sebesar 1600, modus 1480 dan standar devisiasi 72,467 dari hasil keseluruhan hasil penjualan dalam waktu satu tahun sebesar 19340.

d) Tahun 2011 memiliki rata-rata hasil penjualan (mean) sebesar 1840, median sebesar 1840, modus 1760 dan standar devisiasi 85,174 dari hasil keseluruhan hasil penjualan dalam waktu satu tahun sebesar 22080 .

e) Tahun 2012 memiliki rata-rata hasil penjualan (mean) sebesar 2164,17, median sebesar 2155, modus 1870 dan standar devisiasi 192,281 dari hasil keseluruhan hasil penjualan dalam waktu satu tahun sebesar 25970

f) Jadi kesimpulannya bahwa dari hasil penjualan tersebut memiliki rata-rata kenaikan dari tahun ke tahun sebesar 58,752

Data laporan hasil biaya distribusi PT. Prima Athatama Magelang yang diperoleh adalah sebagai berikut :

Tabel 1.3 Laporan Bulanan distribusi 


\begin{tabular}{|c|c|c|c|c|c|}
\hline Bulan & 2008 & 2009 & 2010 & 2011 & 2012 \\
\hline Januari & 132 & 190 & 240 & 290 & 320 \\
\hline Februari & 110 & 200 & 250 & 300 & 380 \\
\hline Maret & 120 & 199 & 230 & 290 & 320 \\
\hline April & 130 & 180 & 250 & 310 & 290 \\
\hline Mei & 172 & 210 & 230 & 320 & 367 \\
\hline Juni & 155 & 190 & 250 & 280 & 350 \\
\hline Juli & 140 & 220 & 240 & 280 & 370 \\
\hline Agustus & 177 & 219 & 266 & 270 & 390 \\
\hline September & 150 & 200 & 246 & 330 & 390 \\
\hline Oktober & 160 & 220 & 250 & 240 & 360 \\
\hline November & 167 & 210 & 270 & 240 & 312 \\
\hline Desember & 184 & 230 & 270 & 288 & 328 \\
\hline
\end{tabular}

Berdasarkan data diatas akan disajikan jumlah mean, modus, median, standar devisiasi dan rata-rata kenaikan biaya distribusi dari tahun 2008, 2009, 2010, 2011, 2012 sebagai berikut :

Tabel 1.4 Data Biaya Distribusi

\begin{tabular}{|c|l|c|c|c|c|c|}
\hline NO & KETERANGAN & 2008 & 2009 & 2010 & 2011 & 2012 \\
\hline 1 & Mean & 149.75 & 205.67 & 249.33 & 285.5 & 348.08 \\
\hline 2 & Median & 152.5 & 205 & 250 & 289 & 355 \\
\hline 3 & Modus & 110 & 190 & 250 & 240 & 320 \\
\hline 4 & Std Deviation & 23.561 & 15.005 & 13.707 & 27.728 & 33.266 \\
\hline 5 & Jumlah & 1797 & 2468 & 2992 & 3438 & 4177 \\
\hline 6 & $\begin{array}{l}\text { Rata-rata } \\
\text { Kenaikan dari } \\
\text { Tahun ke Tahun }\end{array}$ & & & & \\
\end{tabular}

Dari tabel biaya distribusi diatas menunjukkan biaya distribusi :

a) Tahun 2008 memiliki rata-rata biaya distribusi (mean) sebesar 149,75, median sebesar 152,50, modus sebesar 110 dan standar devisiasi 23,561 dari hasil keseluruhan biaya distribusi dalam waktu satu tahun sebesar 1797.

b) Tahun 2009 memiliki rata-rata biaya distribusi (mean) sebesar 205,67, median sebesar 205,00, modus 190 dan standar devisiasi 15,005 dari hasil keseluruhan biaya distribusi dalam waktu satu tahun sebesar 2468 .

c) Tahun 2010 memiliki rata-rata biaya distribusi (mean) sebesar 249,33, median sebesar 250,00, modus 250 dan standar devisiasi 13,707 dari hasil keseluruhan biaya distribusi dalam waktu satu tahun sebesar 2992.

d) Tahun 2011 memiliki rata-rata biaya distribusi (mean) sebesar 286,50, median sebesar 289,00, modus 240 dan standar devisiasi 27,728 dari hasil keseluruhan biaya distribusi dalam waktu satu tahun sebesar 3438 .

e) Tahun 2012 memiliki rata-rata biaya distribusi (mean) sebesar 348,08, median sebesar 355,00, modus 320 dan standar devisiasi 33,266 dari hasil keseluruhan biaya distribusi dalam waktu satu tahun sebesar 4177 .

f) Jadi kesimpulannya bahwa dari biaya distribusi tersebut memiliki rata-rata kenaikan dari tahun ke tahun sebesar 9,307.

Data laporan hasil biaya promosi PT. Prima Athatama Magelang yang diperoleh adalah sebagai berikut :

Tabel 1.5Laporan Biaya Promosi

\begin{tabular}{|c|c|c|c|c|c|}
\hline Bulan & 2008 & 2009 & 2010 & 2011 & 2012 \\
\hline Januari & 60 & 120 & 140 & 150 & 160 \\
\hline Februari & 70 & 120 & 120 & 150 & 130 \\
\hline Maret & 60 & 120 & 130 & 150 & 130 \\
\hline April & 70 & 100 & 130 & 130 & 160 \\
\hline Mei & 80 & 135 & 130 & 120 & 165 \\
\hline Juni & 70 & 120 & 150 & 130 & 160 \\
\hline Juli & 80 & 130 & 140 & 150 & 180 \\
\hline Agustus & 90 & 140 & 130 & 150 & 190 \\
\hline September & 90 & 120 & 130 & 170 & 160 \\
\hline Oktober & 80 & 120 & 140 & 160 & 170 \\
\hline November & 100 & 120 & 160 & 160 & 150 \\
\hline Desember & 100 & 120 & 160 & 150 & 160 \\
\hline
\end{tabular}


Berdasarkan data diatas akan disajikan jumlah mean, modus, median, standar devisiasi biaya promosi dan rata-rata kenaikan dari tahun 2008, 2009, 2010, 2011, 2012 sebagai berikut:

Tabel 1.6 Data biaya promosi

\begin{tabular}{c|l|c|c|c|c|c|}
\hline NO & KETERANGAN & 2008 & 2009 & 2010 & 2011 & 2012 \\
\hline 1 & Mean & 79.17 & 122.08 & 138.33 & 147.5 & 159.58 \\
\hline 2 & Median & 80 & 120 & 135 & 150 & 160 \\
\hline 3 & Modus & 70 & 120 & 130 & 150 & 160 \\
\hline 4 & Std Deviation & 13.79 & 9.876 & 12.673 & 14.222 & 17.381 \\
\hline 5 & Jumlah & 950 & 1465 & 1660 & 1770 & 1915 \\
\hline 6 & $\begin{array}{l}\text { Kata-rata } \\
\text { Kenaikan dari }\end{array}$ & & & & & \\
\hline
\end{tabular}

Dari tabel data biaya promosi diatas menunjukkan biaya promosi :

a) Tahun 2008 memiliki rata-rata biaya promosi (mean) sebesar 79,17, median sebesar 80,00, modus sebesar 70 dan standar devisiasi 13,790 dari hasil keseluruhan biaya promosi dalam waktu satu tahun sebesar 950 .

b) Tahun 2009 memiliki rata-rata biaya promosi (mean) sebesar 122,08, median sebesar 120,00, modus 120 dan standar devisiasi 9,876 dari hasil keseluruhan biaya promosi dalam waktu satu tahun sebesar 1465.

c) Tahun 2010 memiliki rata-rata biaya promosi (mean) sebesar 138,33, median sebesar 135,00, modus 130 dan standar devisiasi 12,673 dari hasil keseluruhan biaya promosi dalam waktu satu tahun sebesar 1660.

d) Tahun 2011 memiliki rata-rata biaya promosi (mean) sebesar 147,50, median sebesar 150, modus 150 dan standar devisiasi 14,222 dari hasil keseluruhan biaya promosi dalam waktu satu tahun sebesar 1770.

e) Tahun 2012 memiliki rata-rata biaya promosi (mean) sebesar 159,58, median sebesar 160,00, modus 160 dan standar devisiasi 17,381 dari hasil keseluruhan biaya promosi dalam waktu satu tahun sebesar 1915.

f) Jadi kesimpulannya bahwa dari biaya promosi tersebut memiliki rata-rata kenaikan dari tahun ke tahun sebesar 4,021 .

Data laporan jumlah pegawai pemasaran PT. Prima Athatama Magelang yang diperoleh adalah sebagai berikut :

Tabel 1.7 Laporan Jumlah Pegawai Pemasaran

\begin{tabular}{|l|c|c|c|c|c}
\hline \multicolumn{1}{|c|}{ Bulan } & 2008 & 2009 & 2010 & 2011 & 2012 \\
\hline Januari & 25 & 30 & 35 & 45 & 50 \\
\hline Februari & 25 & 30 & 35 & 45 & 50 \\
\hline Maret & 25 & 30 & 35 & 45 & 50 \\
\hline April & 25 & 30 & 45 & 45 & 50 \\
\hline Mei & 25 & 30 & 45 & 45 & 50 \\
\hline Juni & 25 & 30 & 45 & 45 & 50 \\
\hline Juli & 30 & 30 & 45 & 45 & 50 \\
\hline Agustus & 30 & 30 & 45 & 45 & 50 \\
\hline September & 30 & 33 & 45 & 45 & 50 \\
\hline Oktober & 30 & 33 & 45 & 50 & 50 \\
\hline November & 30 & 33 & 45 & 50 & 50 \\
\hline Desember & 30 & 35 & 45 & 50 & 50 \\
\hline
\end{tabular}

Sumber Data : PT. Prima Athatama 
Berdasarkan data diatas akan disajikan jumlah mean, modus, median, standar devisiasi jumlah pegawai pemasaran dan rata-rata kenaikan dari tahun 2008, 2009, 2010, 2011, 2012 sebagai berikut :

Tabel 1.8 Data Jumlah Pegawai Pemasaran

\begin{tabular}{|c|l|c|c|c|c|c|}
\hline NO & KETERANGAN & 2008 & 2009 & 2010 & 2011 & 2012 \\
\hline 1 & Mean & 27.50 & 31.17 & 42.50 & 46.25 & 50 \\
\hline 2 & Median & 27.50 & 30 & 45 & 45 & 50 \\
\hline 3 & Modus & 25 & 30 & 45 & 45 & 50 \\
\hline 4 & Std Deviation & 2.611 & 1.801 & 4.523 & 2.261 & 0 \\
\hline 5 & Jumlah & 330 & 374 & 510 & 555 & 600 \\
\hline 6 & $\begin{array}{l}\text { Rata-rata } \\
\text { Kenaikan dari } \\
\text { Tahun ke Tahun }\end{array}$ & \multicolumn{7}{|c|}{1.18} \\
\hline
\end{tabular}

Dari tabel data jumlah pegawai pemasaran diatas menunjukkan jumlah pegawai pemasaran :

a) Tahun 2008 memiliki rata-rata jumlah pegawai pemasaran (mean) sebesar 27,50, median sebesar 27,50, modus sebesar 25 dan standar devisiasi 2,611 dari hasil keseluruhan jumlah pegawai pemasaran dalam waktu satu tahun sebesar 330.

b) Tahun 2009 memiliki rata-rata jumlah pegawai pemasaran (mean) sebesar 31,17 , median sebesar 30,00, modus 30 dan standar devisiasi 1,801 dari hasil keseluruhan jumlah pegawai pemasaran dalam waktu satu tahun sebesar 374 .

c) Tahun 2010 memiliki rata-rata jumlah pegawai pemasaran (mean) sebesar 42,50, median sebesar 45,00, modus 45 dan standar devisiasi 4,523 dari hasil keseluruhan jumlah pegawai pemasaran dalam waktu satu tahun sebesar 510 .

d) Tahun 2011 memiliki rata-rata jumlah pegawai pemasaran (mean) sebesar 46,25 , median sebesar 45,00 , modus 45 dan standar devisiasi 2,261 dari hasil keseluruhan jumlah pegawai pemasaran dalam waktu satu tahun sebesar 555.

e) Tahun 2012 memiliki rata-rata jumlah pegawai pemasaran (mean) sebesar 50,00 , median sebesar 50,00, modus 50 dan standar devisiasi 0,000 dari hasil keseluruhan jumlah pegawai pemasaran dalam waktu satu tahun sebesar 600 .

f) Jadi kesimpulannya bahwa dari jumlah pegawai pemasaran tersebut memiliki rata-rata kenaikan dari tahun ke tahun sebesar 1,180 .

\section{B. Persamaan Regresi Berganda}

Berdasarkan hasil penelitian biaya distribusi berpengaruh terhadap hasil penjualan (Y). Adapun nilai koefisien regresi variabel distribusi sebesar 2.155 hal ini menunjukkan bahwa apabila biaya distribusi dinaikkan Rp. 1,00 akan mampu mempengaruhi hasil penjualan (Y) di PT. Prima Athatama Magelang. Agar hasil penjualan seperti yang diharapkan yaitu terjadi kenaikan sebesar angka tersebut, maka PT. Prima Athatama perlu 
meningkatkan biaya distribusi yang telah dilakukan.

Biaya promosi juga berpengaruh terhadap hasil penjualan (Y) dengan koefisien regresi sebesar 1.312 hal ini menunjukkan bahwa apabila biaya promosi dinaikkan Rp. 1,00 akan berpengaruh terhadap hasil penjualan. Nilai koefisien regresi tersebut lebih kecil dibandingkan dengan boaya distribusi. Oleh sebab itu maka PT. Prima Athatama harus meningkatkan biaya promosi supaya konsumen lebih tertarik terhadap promosi yang dipromosikan dengan membuat beberapa alternative semisal lebih memperbanyak promosi langsung ke konsumen.

Jumlah pegawai pemasaran juga berpengaruh terhadap hasil penjualan $(\mathrm{Y})$. Adapun nilai koefisien regresi variabel jumlah pegawai pemasaran sebesar 28.727 hal ini menunjukkan bahwa apabila jumlah pegawai pemasaran dinaikkan 1 satuan akan mempunyai pengaruh dari hasil penjualan. Nilai koefisien regresi jumlah pegawai pemasaran lebih besar dari biaya distribusi dan biaya promosi hal ini berarti jumlah pegawai pemasaran sudah cukup memadahi sesuai yang diharapkan PT. Prima Athatama.

\section{Uji Hipotesis}

Dengan menggunakan $t$ hitung dapat diartikan bahwa biaya distribusi menerima Ha dan Ho ditolak berarti ada pengaruh yang signifikan terhadap hasil penjualan yaitu $3.623 \geq 1.672 \mathrm{t}$ hitung lebih besar dari $t$ tabel. Biaya promosi berpengaruh terhadap hasil penjualan dan menerima $\mathrm{Ha}$ menerima $\mathrm{Ha}$ dan $\mathrm{Ho}$ ditolak yaitu $2.101 \geq 1.672 \mathrm{t}$ hitung lebih besar dari $\mathrm{t}$ tabel dan jumlah pegawai pemasaran terhadap hasil penjualan menerima Ho yaitu $6.271 \geq 1.672$ t hitung lebih besar dari $t$ tabel. Jadi penghitungan menggunakan $\mathrm{t}$ hitung semua variabel biaya distribusi, biaya promosi dan jumlah pegawai pemasaran berpengaruh terhadap hasil penjualan di PT. Prima Athatama Magelang.

Dengan menggunakan F hitung dapat diartikan bahwa menerima Ha dan Ho ditolak yaitu $204.811 \geq 3.162$ F hitung lebih besar dari $\mathrm{F}$ tabel berarti variabel biaya distribusi, biaya promosi dan jumlah pegawai pemasaran secara bersama-sama mempunyai pengaruh yang signifikan terhadap hasil penjualan di PT. Prima Athatama Magelang.

Dengan menggunakan koefisien determinasi dapat diartikan $91.6 \%$ hasil penjualan dapat diartikan bahwa variabel biaya distribusi, biaya promosi dan jumlah pegawai pemasaran dapat menjelaskan hasil penjualan, dan jika terjadi sisanya $8.6 \%$ maka variabel independen tidak dapat menjelaskan atau membuktikan tentang variabel dependen. 


\section{Uji Asumsi Klasik}

Dengan menggunakan uji

Heteroskendastisitas maka semua variabel berada di daerah penerimaan Ho yaitu :

a. Biaya distribusi $-1.672 \leq 1.175 \leq 1.672$

b. Biaya promosi $-1.672 \leq-0.266 \leq 1.672$

c. Jumlah pegawai pemasaran $-1.672 \leq$ $-0.657 \leq 1.672$

Bahwa variabel model persamaan ini tidak terkena gejala Heteroskendastisitas. Dalam Uji Autocorrelation ini terjadi adanya gejala penyakit Autocorrelation dapat dibuktikan dengan adanya hubungan antara RES_1 dengan RES_2 t hitung 4.347 dan sig 0.000 dari RES_1

Dalam Uji multikolinieritas dapat dibuktikan dengan nilai toleransi dan VIP yaitu nilai toleransinya 0.323 dan VIP 4.315 dalam hal ini biaya promosi yang lolos dari uji multikolinieritas dan biaya distribusi dan jumlah pegawai pemasaran tidak lolos uji multikolinieritas karena nilai VIP nya lebih dari 5(lima). Tetapi dalam pengujian multikolinieritas semua nilai toleransinya kurang dari 5 (lima) dan dapat dikatakan semua telah lolos Uji multikolinieritas. Pada tabel coefficient correlations dapat dilihat matriks korelasi, dari ketiga variabel independen yang dipakai, yang korelasinya cukup besar adalah hubungan antara variabel pegawai yang nilainya sebesar -0.594 atau sebesar $5.95 \%$, tetapi karena korelasi masih dibawah 90 \% maka bias dikatakan, bahwa variabel independen yang dipakai tidak ada yang memiliki gejala multikolinieritas.

\section{E. Uji Normal Kolmogorov-Smirnov}

Dari hasil pengujian untuk menentukan nilai $\mathrm{P}$ dapat dilihat di Asymp. Sig. (2-tailed), dapat di kreteriakan sebagai berikut :

a) Nilai Sig atau nilai $\mathrm{P}$ variabel distribusi $=0.919>0.05$ maka data dikatakan Normal

b) Nilai Sig atau nilai P variabel promosi $0.075>0.05$ maka data dikatakan Normal

c) Nilai Sig atau nilai P variabel pegawai $0.127>0.05$ maka data dikatakan Normal

d) Nilai Sig atau nilai $P$ variabel penjualan $0.526>0.05$ maka data dikatakan Normal

Berdasarkan hasil diatas maka dapat disimpulkan bahwa semua variabel biaya distribusi , biaya promosi jumlah pegawai pemasaran dan hasil penjualan (Y) semuanya lebih besar dari pada 0.05 sehingga distribusi datanya adalah Normal.

\section{SIMPULAN DAN SARAN}

\section{A. Simpulan}

Hipotesis yang berbunyi variabel biaya distribusi, variabel biaya promosi dan variabel jumlah pegawai pemasaran secara persial mempunyai pengaruh yang signifikan terhadap hasil penjualan $(Y)$ di 
PT. Prima Athatama Magelang terbukti karena dari hasil pengujian $t$ hitung diperoleh nilai $\mathrm{t}$ hitung lebih besar daripada t tabel yaitu $3.475>1.672$, berarti Ho ditolak dan Ha diterima, maka terbukti variabel biaya distribusi, variabel biaya promosi dan variabel jumlah pegawai pemasaran secara bersama-sama mempunyai pengaruh yang signifikan terhadap hasil penjualan (Y) di PT. Prima Athatama Magelang

Hipotesis yang berbunyi variabel biaya distribusi , variabel biaya promosi dan variabel jumlah pegawai pemasaran secara simultan mempunyai pengaruh yang signifikan terhadap hasil penjualan (Y) di PT. Prima Athatama Magelang terbukti karena dari hasil pengujian $\mathrm{F}$ hitung diperoleh nilai $\mathrm{F}$ hitung lebih besar daripada F tabel yaitu $204.811>3.162$, berarti Ho ditolak dan Ha diterima, maka terbukti variabel biaya distribusi , variabel biaya promosi dan variabel jumlah pegawai pemasaran secara bersama-sama mempunyai pengaruh yang signifikan terhadap hasil penjualan (Y) di PT. Prima Athatama Magelang

\section{B. Saran}

PT. Prima Athatama Magelang memperhatikan citra perusahaan (corporate image) dengan berusaha menjaga hubungan yang harmonis dan berkesinambungan antara PT. Prima
Athatama Magelang dengan masyarakat sekitar.

Untuk meningkatkan hasil penjualan, maka sebaiknya PT. Prima Athatama Magelang lebih meningkatkan biaya distribusi, biaya promosi dan jumlah pegawai pemasaran sehingga dapat dikeluarkan secara efisien sehingga jangkauannya lebih luas.

\section{DAFTAR PUSTAKA}

Haider F. Abdul Amir. 2004. Modul Praktikum Statistik Deskriptif SPSS.Yogyakarta.

Kotler, Philip. 2000. Marketing. Jakarta: Erlangga

Swastha dan Irawan. 2002. Manajemen Pemasaran Modern. Yogyakarta: Liberty

Swastha, Basu. 2004. Azas-azas Marketing. Yogyakarta: BPFE

Swastha, Basu. 2004. Manajemen Penjualan. Yogyakarta

Stanton, William J.2000. Manajemen Pemasaran. Jakarta: Erlangga

Lupiyoad., 2001. Marketing Mix. Jakarta: Erlangga

Marom, Chairul . 2002. Sistem Akuntansi Perusahaan Dagang. Jakarta: Erlangga

Azwar, Saifuddi. 2007. Analisis Data. Yogyakata

Gujarati, Damodar. 1997, Ekonometrika Dasar. Jakarta : Erlangga 